Article

\title{
When Colour Matters: Policing and Hate Crime
}

Berit Wigerfelt, Anders S. Wigerfelt and Jenny Kiiskinen

Malmö Institute for Studies of Migration, Diversity and Welfare, Malmö University, 20506 Malmö, Sweden;

E-Mails: berit.wigerfelt@mah.se (B.W.); anders.wigerfelt@mah.se (A.S.W.); jenny.kiiskinen@mah.se (J.K.);

Tel.: +46-40-665-73-48 (B.W.)

\section{How to Cite this Article}

Wigerfelt, B., Wigerfelt, A. S., \& Kiiskinen, J. (2014). When Colour Matters: Policing and Hate Crime. Social Inclusion, 2(1), 1-11.

\section{Copyrights}

(C) 2014 by the authors; licensee Cogitatio (Lisbon, Portugal). This article is licensed under a Creative Commons Attribution 4.0 International License (CC BY).

\section{Published by:}

\section{COGITATIO}

www.cogitatiopress.com

\section{About the Journal}

Social Inclusion is a peer-reviewed open access journal which provides academics and policy-makers with a forum to discuss and promote a more socially inclusive society. The journal encourages researchers to publish their results on topics concerning social and cultural cohesiveness, marginalized social groups, social stratification, minority-majority interaction, cultural diversity, national identity, and core-periphery relations, while making significant contributions to the understanding and enhancement of social inclusion worldwide.

www.cogitatiopress.com/socialinclusion

Editor-in-Chief

Professor Ulf R. Hedetoft, Faculty of Humanities, University of Copenhagen, Denmark

Managing Editor

Mr. António Vieira, Social Inclusion, Cogitatio Press, Portugal 
Article

\title{
When Colour Matters: Policing and Hate Crime
}

\author{
Berit Wigerfelt *, Anders S. Wigerfelt and Jenny Kiiskinen \\ Malmö Institute for Studies of Migration, Diversity and Welfare, Malmö University, 20506 Malmö, Sweden; \\ E-Mails: berit.wigerfelt@mah.se (B.W.); anders.wigerfelt@mah.se (A.S.W.); jenny.kiiskinen@mah.se (J.K.); \\ Tel.: +46-40-665-73-48 (B.W.)
}

* Corresponding author

Submitted: 13 January 2014 | In Revised Form: 8 February 2014 | Accepted: 25 March 2014 |

Published: 21 April 2014

\begin{abstract}
Contrary to the image of Sweden as a tolerant, colour-blind and non-racial country, which is based on the narrative of a country for instance associated with solidarity with the so-called Third World; in this article we argue that racial attributes, e.g. visible differences, account for people's different life possibilities and circumstances in Swedish society. This article explores and discusses whether, and if so why, people who belong to the group that is categorised as "nonwhite", with an emphasis on Afroswedes, and depicted as racially different, experience being targets of diverse variations of bias-based policing, harassment and hate crime. Theories relating to colonial stereotypes, racism, doing difference, the geography of hate, race/ethnicity profiling and intersectionality are used to analyse our material. Based on individual and focus group interviews with "non-whites", this article discusses how visible differences are highlighted in different kinds of social contexts. The interview results show that people with dark skin are often targets of different kinds of private and public policing based on race- and ethnicity profiling that often occurs on or near borders/boundaries. When those who are targets of racial harassment and exclusion resist such treatment, e.g. by crossing borders/boundaries, they are at risk of becoming victims of hate crime.
\end{abstract}

\section{Keywords}

borders; hate crime; private policing; public policing; race and ethnicity profiling

\section{Issue}

This article is part of the regular issue of Social Inclusion, edited by Professor Ulf R. Hedetoft (University of Copenhagen, Denmark).

(C) 2014 by the authors; licensee Cogitatio (Lisbon, Portugal). This article is licensed under a Creative Commons Attribution 4.0 International License (CC BY).

\section{Introduction}

Since 2003 a number of murders and attempted murders have been reported in Malmö, Sweden's third largest city with some 300,000 inhabitants. These offences have mainly been directed at people with dark skin/hair. In October 2010 the police indicated that they were looking for a suspected serial shooter who fired his gun at night at dark-skinned people in various parts of Malmö. In a city in which about 40 per cent of the population has some kind of migration background, many of them having dark phenotypical markers, this communiqué caused considerable fear among "nonwhites". Finally, in November 2010, the police arrested 39-year-old Peter Mangs, who was later sentenced to life imprisonment. Despite their brutality, the murders and attempted murders for which Mangs was condemned are not unique to Sweden or to other countries. The serial shootings in Malmö can also be seen as part of an historical continuity, where racism has at different periods assumed differing expressions and intensities (Wigerfelt \& Wigerfelt, 2014).

Mangs' actions exemplify the violent and extreme expressions of racist hate crime that are directed against "non-whites" in Sweden. In this article we refer to such actions as "private policing". Private policing can be carried out by private individuals or by groups of people, such as extreme right-wing groups. These 
actions are usually unlawful and are condemned by the majority society. Perpetrators who carry out criminal acts where the motive is racial violation can be given stiffer sentences. Such actions are often called hate crimes (Wigerfelt \& Wigerfelt, 2014). ${ }^{1}$

What we label "public policing" is a concept that in this context refers to individuals/groups that are sanctioned by society to legitimately exercise violence, most often the police. The police are supposed to protect the rights of individuals and groups and prevent them from being exposed to e.g. hate crimes. Despite this, numerous stories are told by people who have been subjected to police harassment. One common denominator is that many "non-whites" feel that the police use racial- and ethnicity profiling to target people with a "non-white" appearance. Narratives about how people have been subjected to police harassment raise questions about whether "non-whites" have the same rights as "whites" and are seen and treated as "real Swedes". They also raise questions about the kind of protection that hate crime legislation gives to victims in practical terms.

An important point of departure in this article is that different ethnic/racial groups have different prerequisites in Swedish society, with structurally different positions towards the majority population and towards each other. In this article we focus on people with dark phenotypical markers, especially Afroswedes, who are often referred to as "blacks" in Sweden, and their experiences of both "private" and "public" policing. This is a category that is exposed to different kinds of everyday harassment and policing based on race profiling.

Notions about blacks have deep historical roots and there are many indications that ideas and discourses about blacks being inferior to whites continue to dominate (Hübinette, Beshir, \& Kawesa, 2014). These ideas are embedded in representations and structures and are often manifested as everyday insults, harassment and racial violence (Berg, 1997; Catomeris, 2004; Granqvist, 2001). However, 20th century Swedes largely regarded themselves as far-sighted, tolerant and non-racial-a self-image that was based on the narrative of a country associated with Social Democracy, the Welfare State, neutrality in World War II and solidarity with the so-called Third World (Pred, 2000; Sawyer, 2000). This self-image has resulted in the denial of the existence of racist structures in present-day Swedish society and an emphasis on racial categorisations (Hübinette, Hörnfeldt, Farahani, \& Rosales, 2012; Pred, 2000). Ideas about Swedishness are closely connected to appearance. Despite this, using the word race in

\footnotetext{
1 The ruling about harsher sentences was introduced in Sweden in 1994 for crimes committed against a person, ethnic group or other groups of people on the grounds of race, skin colour, national or ethnic origin, faith, sexual orientation or other similar circumstances (The Swedish Penal Code Ch.29, 2 § 7 p.).
}

Sweden is almost taboo. This has led to difficulties in addressing problems such as racism and hate crime. As Goldberg (2006) states, there is an unwillingness in most countries in Europe to recognise that race matters-a form of colour-blindness that assumes that appearance is irrelevant (Bonilla-Silva, 2010). But as we will show in this article, phenotypical markers, or visible differences, are still important for explaining people's different life possibilities and circumstances in Swedish society.

According to official statistics, about 100,000 people in Sweden-the equivalent of one per cent of Sweden's total population of around 10 million-have been exposed to racial hate crime in recent years (Brå, 2013). In 2012 some 4,000 racial hate crimes were reported to the police, which amounted to about 72 per cent of the total number of hate crime notifications. Studies (Kalonaityté, Kawesa, \& Tedros, 2007; Motsieloa, 2003; Pred, 2000; Sawyer, 2000; Schmauch, 2006) have also shown that in Sweden people with dark skin are often subjected to racial harassment, discrimination, stereotyped ideas and prejudices.

Listening to victims' stories is vital if we are to gain access to and understand openly manifested racism and more subtle expressions of racial prejudice and stereotypes. In this study this has led us to focus on the victims' experiences and to allow them to contribute to the discussion. Helen Ahn Lin (2009) draws attention to the fact that researchers seldom ask how racial minorities define, experience and deal with the exposure that follows in the wake of race profiling and racism. Against this background, the purpose of the study is to:

Explore and discuss whether, and if so why, people who belong to the group that is categorised as "non-white", with an emphasis on Afroswedes, experience being the targets of different kinds of policing, harassment and hate crime.

\section{Theory and Previous Research}

Different historical events and processes have led to different interpretations of racism. Racism also occurs at different social levels and in different contexts (Brah, 1993). Harassment, exclusion and violence are expressed differently depending on how individuals are categorised. The expressions differ in terms of the practices and discourses that legitimise them. We can talk about a variant of a racist discourse which, according to van Dijk (1993), can be seen as an underlying collection of systematised notions about phenotypes, distinguishing features and power hierarchies. For example, racism as a discourse can create and preserve ideas about skin colour, and phenotypical markers can be linked to cultivation, intellectual development and cultural affiliation. 
Representations of people who are perceived as "non-white" build on stereotypes that reduce people to a few simple, essential characteristics that are decided upon by nature. According to Hall (1997), stereotyping is a signifying practice that is central to the representation of racial difference. Another feature of stereotyping is that it symbolically fixes boundaries and excludes everything that does not belong. As Goldberg (2006, p. 358) writes, "...borders are often constituted through race..."

When borders/boundaries (Alvarez, 1995; Fassin, 2011; Lamont \& Molnár, 2002) are threatened, and when subordinated groups seek to redefine their positions and manifest difference in a way that the perpetrators find unacceptable, the threat has to be suppressed by the perpetrators in order to confirm the hegemonic group's supremacy. The tensions between hegemonic and anti-hegemonic actors can culminate in violent exertions to restore the dominance of the former (Perry, 2003). It is in this context that exclusion, harassment and hate crime become resources for doing difference and punishing those who test the boundaries (Perry, 2001, pp. 60-61). Different categories like race, ethnicity, gender, class and sexuality can often form the basis for exclusion. In this context, the concept of intersectionality can be used to show how different kinds of subordination can be carried out at the same time and can influence and recreate each other (Crenshaw, 1991; Yuval-Davis, 2011).

Paradoxically, some perpetrators have construed themselves as victims by demarcating "Us" and "Them". From the perpetrators' perspective, violence is legitimate because they use it to protect themselves and "their" territory from the threat of outsiders (Green, Strolovitch, \& Wong, 1998; McDevitt, Levin, \& Bennett, 2003; Ray \& Smith, 2001) by means of "private policing". Historical notions of race and belonging can thus be integrated with present-day apprehensions about the right to a certain territory. This is sometimes referred to as "the geography of hate" (Anthias \& YuvalDavis, 1992; Gadd \& Dixon, 2009, p. 80; Perry, 2009, p. 67). The effect of "private policing" is that the perpetrator, via the victim, sends a message (Sumartojo, 2004) to members of the target group that they are not welcome. There are sometimes grey zones between "private policing" and the official "public policing" that we think ought to be highlighted and problematized. Like "private policing", "public policing" also uses criteria based on race and ethnicity, for example in the form of race profiling. "Private policing" can often be linked to individuals and groups with more or less openly racist views that can also be reported and convicted as hate crime. However, those who engage in "public policing" as part of their duties, and to all intents and purposes have the law on their side, can also act in a bias-based way.

The concept of race profiling, which is sometimes called bias-based policing, is mostly used in British and
American research and means that the police use race to stop and interrogate citizens (Rice \& White, 2010; Weitzer \& Tuch, 2002, p. 435). The research studies indicate that people who belong to minority groups, such as African Americans, are stopped, searched and given fines to a greater extent than white people (Hübinette, Hörnfeldt, Farahani, \& Rosales, 2012; Jones-Brown \& Maule, 2010; Petrocelli, Piquero, \& Smith, 2003; Weitzer, 2010).

A concept that is often used in American research is "driving while black". This refers to the fact that black drivers are stopped by the police more often than other categories of people (Lambert, 2010). Although it is not always possible to transfer American research to another context, a report written by Lappalainen (2005) shows that in Sweden people with a foreign background run a greater risk of being stopped by the police, searched, arrested, detained and sentenced to prison than native Swedes in a similar situation. Such treatment of minority groups by the police is sometimes called "over-policing" (Bowling \& Phillips, 2002). The report also shows that people with roots outside Europe have less confidence in the police and courts than native Swedes. Research shows that in many cases people are understood as belonging to minority groups to the extent that the police either do not care about them being exposed to different types of crime or give these crimes high priority, which is usually referred to as "under-policing" or "under-protection" (Hall, 2005).

\section{Method and Material}

This article is mostly based on interviews conducted within the project entitled Hate Crime-A Challenge to Democracy. This is a multidisciplinary study on hate crime in Skåne that focuses on the causes, consequences and support initiatives, and is financed by the Swedish Research Council. The project studies groups that are often exposed to hate crime, such as Jews, Muslims, Afroswedes, Romany/Travellers and the LBTG community, and this article is based on one of the project's sub-studies.

In this article, the focus is on those who are perceived as "non-white", with an emphasis on Afroswedes' experiences of different kinds of policing, racism, discrimination, everyday harassment and hate crime. In our study we have made use of legal records and transcripts and have also observed court cases. The study is primarily based on individual interviews (15). Some of the informants were interviewed several times. The informants - seven men and eight women aged between 20 and 61 years - mainly live in southern Sweden and are given fictitious names in the text. The informants have different nationality, class and religious backgrounds. We have come into contact with these people via The Pan African Movement for Justice (an inde- 
pendent political and religious organisation for people with an African background), anti-discrimination offices and personal contacts that have led to other contacts through the snowball method. Café Pan Africa is a meeting place in Malmö where people meet once a week in order to discuss issues that concern Africans. One of the Café's leading members has served as gatekeeper (Bryman, 2012, p. 384-386) and has helped us to make contact with a variety of informants. On two separate occasions in 2012 and 2013 the authors were invited to meetings attended by a total of 37 people, where we were able to conduct focus group interviews. In the first focus group interview we learned how Afroswedes experienced the issues discussed in the article, and in the second we had an opportunity to test our preliminary results and conclusions. The focus groups also highlighted the experiences (Bryman, 2012, pp. 446-449) that Afroswedes encounter regularly in Swedish society. We are aware that our interviews may be somewhat biased, in that we looked for people who had been exposed to different kinds of policing, hate crime and incidents that could be interpreted as hate crime, which is the research study's expressed purpose. Those who volunteered to be interviewed regarded themselves as having been exposed to some kind of special treatment due to the colour of their skin and communicated representations of these experiences. We stopped collecting data when we considered that a "theoretical saturation" (Bryman, 2012, p. 394) point had been reached and when the results of the themes that were taken up in the interviews showed great similarities with each other. Although the results of the study do not claim to generalise or represent the experiences of all people with dark phenotypical markers in Sweden, they do indicate that people with dark skin and other phenotypical markers who are not considered to conform to white norms are all too often discriminated against and treated differently. In the article we have chosen to allow many of the informants to speak for themselves by making use of short yet representative quotations from the interviews we conducted. We have also used longer narratives that we think illustrate our conclusions and thereby create a greater understanding of the problems.

All the interviews except one were conducted in Swedish and lasted between one and two hours (the other was conducted in English in the same space of time). Each interview was tape-recorded and transcribed. The focus group interviews lasted for three hours. The authors have made minor revisions to the language used in the interview quotations when translating from Swedish to English, but in that process have tried to keep as close as possible to the original.

Data was collected and analyses were conducted throughout the research process. The interview guide was revised regularly to suit the varying circumstances; questions were added and some were omitted. The analysis began by listening to the taped interviews and reading the transcriptions and documentation. The interviews were coded according to the central themes that had been identified during the above process, and comparisons of the authors' various interpretations were made. The coding was revised in the light of the researchers' interpretations. Theoretical concepts were then applied in order to analyse the interpretations. This led to new questions, which were addressed by returning to the empirical material-an abductive process that was enhanced by alternating between theory and empirical material (Alvesson \& Sköldberg, 1994). We analysed the date using various grounded theory techniques (Charmaz, 2006) and narrative analysis. Miller (2000) maintains that narrative interviews in studies based on life stories or biographical research are much more oriented towards eliciting the interviewee's perspective than objective facts. To a great extent the interviewer is part of the process in that he or she is included in the construction of the interviewee's story.

\section{Result and Analysis}

\subsection{Does Race Matter in Sweden Today?}

Claiming that race has a role to play in Sweden today is more or less taboo (Hübinette, Hörnfeldt, Farahani, \& Rosales, 2012). Despite this, there is considerable evidence to suggest that in Sweden phenotypical markers are important in many people's daily lives. People with a skin colour other than white feel that these markers distinguish them from the white majority population in a negative way in certain situations.

Thomas, who originates from Gambia and has lived in Sweden for over 30 years, responded to the question of whether race/skin colour meant anything in presentday Sweden in the following way:

Yes, it does. I inwardly feel that it is an obstacle. Very much so. As black in Sweden. Just because one is black people think that this black person cannot do much or know much...It means that certain things pass you by and go to someone with a lighter skin-white or whatever (Interview, 20-03-2013).

Thomas claims that he is branded on the basis of the colour of his skin and his cultural background, and that there are perceptions about him coming from a lowstatus culture. It is not just about him feeling vulnerable, but also that he is emotionally affected by others with an African background being harassed; something that he shares with others in the focus group (Focus group 28-11-2013).

Jennifer experiences that her work colleagues use racist language (nigger) and that when she protests the response is: "We've always said this" (Interview, 24-042012). Being continuously exposed to a kind of low-key 
racism has a very damaging effect on many people (Focus group 14-09-2012 and Focus group 28-11-2013). As Eva said in an interview: "It's very draining...you really feel devastated..." (Interview, 10-12-2012).

Serial shooter Peter Mangs, named in the introduction to this article, is a violent example of "private policing". In the autumn of 2010 the police in Malmö publicly announced that a serial shooter was on the loose who appeared to select his victims on the basis of race. This warning created panic in Malmö, and narratives expressing caution and fear are manifold. Maria said in an interview that prior to Mangs being arrested the fear about what the serial shooter might do next was more or less the only thing that her friends and family talked about:

One day when I was out with my mother and we were going to collect a friend we waited in the car outside her door. We saw a man who reached for his mobile phone in his jacket pocket and we all screamed. Everyone was on guard and on the lookout and suspected everyone. It was awful (Interview, 22-11-2012).

This fear was also very apparent in the focus group interviews. There, several of the participants talked about how afraid they were of being out of doors, and how they dimmed the lights when they were at home. For many their worst fear was that something might happen to their children. Some of the informants tried to disguise themselves by wearing voluminous garments when walking about outside (Focus group 14-092012 and Focus group 28-11-2013).

The perpetrator sent a message to members of the target group that they should not be in the country at all and risked death if they remained (Sumartojo, 2004). Skin colour and dark phenotypical markers became criteria for whether one felt safe or not in Malmö during the period when Peter Mangs was on the rampage.

Other actions that "non-whites" said that they experienced as racist were more mundane in nature (Essed, 1991), but were seldom regarded by the majority society as racist.

Colonial and stereotyped ideas about people with dark skins live on. They are embedded in representations and structures and can be expressed in the form of everyday insults, as well as in forms of racial violence and bias-based policing (Hall, 1997; Rice \& White, 2010; Wigerfelt \& Wigerfelt, 2014).

Two examples of notions of race associated with "public policing" are Tina's and Cecilia's stories of how they experience that the police harass them due to the colour of their skin. Tina, who is originally from Somalia but has grown up in Sweden, lives in Malmö. In 2013 the police knocked on the door and wanted to search her flat because they thought that they would find "paperless" refugees hiding there. Tina claims that this was due to the colour of her skin and says that some of her Afroswede friends have also been subjected to similar controls as a result of their dark phenotypical markers (Interview, 04-04-2013). Another example is Cecilia, an Afroswede, who was standing talking to a friend when a police car passed by and stopped when its occupants saw Cecilia's dark skin: "They demanded to see my identity card and said that if I didn't produce it they would take me to the police station...just because of the colour of my skin" (Interview, 10-032013).

\subsection{Hate Crime as a Punishment for Those Who Cross Boundaries}

Most of the people we interviewed did not accept their inferior position, vulnerability and exclusion, but in different ways wanted to change the views towards and treatment of people with dark skin. This can take different expressions, such as not remaining silent in the face of verbal abuse and by reporting incidents to the police or the Equality Ombudsman. Other ways include demonstrations and political struggle (Focus group 1409-2012 and Focus group 28-11-2013).

Patric comes from an African country, but has lived in Malmö for many years. He is a person who does not think of himself as inferior and is active in associations that are trying to combat racism. An avalanche of hate was released when Patric reported a student association at Lund University-the largest university in southern Sweden. Some students had dressed up as slaves at a party. They had blacked their faces, put ropes around their necks and were sold as slaves to a white "slave dealer" in an auction. Patric, who got to know about this, reported the incident to the police as "incitement to racial hatred" and condemned the action in the media. Patric and many others regarded the slave auction and its connection to colonial stereotypes as racist, while the students claimed that it was an innocent prank and that Patric was over-sensitive.

Patric's reporting of the "slave auction" to the police triggered a chain of actions. Different actors tried to restore order by "private policing". One of these actors was Stan. He made a poster with the words "Our negro slave has escaped" and a picture of Patric, and displayed it in various places. The picture was created as a montage, with Patric's face mounted on the naked torso of Kunta Kinte, with a big chain and leash around his neck. Stan was caught pasting up some of the posters and was later prosecuted. Patric reacted strongly: "I am perceived as an enslaved African. It is a disparaging and offensive picture, I am depicted as an animal" (Interview, 20-03-2012).

The District Court in Lund, and later the Court of Appeal in Malmö, found Stan guilty of slander and incitement to racial hatred and gave him a suspended sentence (District Court in Lund Verdict 26-01-2012, 
Case No. B 3156-11, 2012; Skåne and Blekinge Appeal Court Verdict 25-04-2013, Case No. 3468-12, 2013).

On racist Internet sites Patric is still taunted by numerous "jokes" associating blacks with slavery, criminality and apes and by direct threats: "We will shoot you and your little chimps. We know where you live". Even though no-one in the focus groups had received death threats, many had been subjected to insults on the Internet due to their African origins (Focus group 14-09-2012 and Focus group 28-11-2013).

According to Barbara Perry, it is in situations in which subordinated groups seek to redefine their placing in the hierarchy and carry out actions that no longer confirm the hegemonic group's supremacy that hate crime becomes a resource with which to punish those who test the boundaries (Perry, 2003).

Patric can be regarded as a person who does not accept insults. This makes him more of a target for hate crime. Violence and everyday offences against those considered as different, or aliens, have long been part of a repertoire to strengthen positions of social and political superiority, and are used to remind "Others" of their place. If they step outside the geographically and politically constructed borders/boundaries of permitted behaviour, they are confronted with reminders of their subordinate status. Regardless of whether this is in the form of everyday harassments or brutal violence, the message is the same: adapt to the standards determined by the white majority, or risk its wrath (Perry, 2001, p. 5).

\subsection{The Crossing of Geographical Borders}

As already indicated, the borders/boundaries that are "crossed" can be social, racial or geographical. For many with phenotypically dark markers it often means being challenged and subjected to "public policing" based on race and ethnicity profiling when crossing the border into Sweden. According to our informants this is a frequent occurrence, especially among men (Focus group 14-09-2012 and Focus group 28-11-2013). Thomas points to such frontiers as places and situations that he has experienced as most unpleasant:

It is very delicate. One of the most sensitive moments. When you come back from Denmark or from abroad. How you are treated at the border. I have experienced this several times. I arrive with my [white] colleagues after having been in Denmark and I am singled out from the rest. My colleagues get angry and I feel belittled and sad. They ask me to produce identification. 'Do you live here?' 'Do you speak Swedish?' Lots of people experience the same thing. It's awful. You are stopped almost every time. It is humiliating (Interview, 2003-2013).
Sara also had negative experiences of crossing borders when she travelled with her father as a teenager and they were always stopped:

And my father's reaction was always to begin shouting, throw down his mobile phone and get really angry. It happened every time. Every time we planned to travel abroad we had to prepare ourselves mentally for it. He was always stopped. Always. And you saw lots of others, white Swedes and others, who were not stopped. Who just walked through. But he was stopped because he was black (Interview, 26-042012).

The border in question here is between the two EU countries of Sweden and Denmark. The idea is that EU citizens should have free mobility. Researchers Sophie Hydén and Anna Lundberg point out that as it is not possible to separate Swedish citizens from people regarded as "unauthorised" in a factual, objective or definitive way, there is a great danger of people being subjected to intervention as a result of their appearance or ethnic background (Hydén \& Lundberg, 2004). For many "non-whites" the treatment they receive at geographical borders is often unpleasant, because skin colour and dark features mean that they are stopped so that "Swedishness" can be determined. According to our informants, if you are black you are not regarded as Swedish (Focus group 14-09-2012 and Focus group 28-11-2013).

On Peter's first encounter with Sweden some twenty years ago, something happened that he experienced as deeply insulting. Peter landed at Arlanda airport and was about to go through security control when he-the only person who was black-was stopped. His passport and other papers were in order, but he was nevertheless forced to remove his clothes and undergo a thorough search, which was carried out in a humiliating way in front of the staff without any explanation whatsoever.

One of the police officers was a woman, and a man stood here with his pistol. I was really, really frightened. I took off all my clothes and felt so humiliated! And they told me to bend down and open my mouth and put a pen in my mouth and checked my tongue. And I was so humiliated and thought: Is this how they treat people? They didn't do this to anyone else. And it might have been a criminal who walked through, but they didn't think like that, but rather, a black, he must be a criminal, he must be carrying drugs. My first day in Sweden. I was there for an hour before they let me go (Interview, 22-03-2012).

As the case with Peter shows, "public policing" at border controls can involve violations based on prejudice and notions of race, visible difference, and in some cases violence towards those who are regarded as nonSwedes/non-whites. Another example is Michael, who 
was involved in an incident at the bridge border crossing between Denmark and Sweden, which he experienced as so offensive that he reported the police to the Parliamentary Ombudsman. Michael was stopped by the police and breathalysed. Although the test was negative, the police asked Michael to get out of the car because they suspected drug- and unlawful driving. All his documentation was in order. Michael stumbled when he was pulled out of the car by a policeman who then tripped over him, which led to four more policemen rushing over to push Michael to the ground. He was sprayed with a pepper spray and handcuffed. Michael was driven off to hospital where he had to undergo two blood tests. He was finally held in custody overnight without any possibility of phoning his family. According to Michael, from the moment he was arrested the police acted violently and aggressively towards him, which caused him pain and was experienced as very abusive. This incident has resulted in Michael now feeling afraid and stressed whenever he sees a police officer. Michael is convinced that all this happened because he was black: "People just judge a person by his colour" (Interview, 18-12-2012). Similar incidents of black men being subjected to police violence have recently been reported in the media. Several people also talked about similar incidents in the focus group interviews (Focus group 14-09-2012 and Focus group 28-11-2013).

The police's duty is to protect people from crime, although our informants sometimes see the police as perpetrators of harassment and hate crime based on race and ethnicity. Experiencing that people in responsible positions, such as the police, violate and discriminate against those identified as "non-white" leads the victims to doubt the state and the system (Harries, 1999). Against this background, some of the informants regard the difference between "private and public policing" as negligible, because in both cases the consequences are often perceived as negative, and feel that reporting such incidents to the police is futile.

\subsection{An Intersectional Dimension}

Being black, a woman and a Muslim can mean several kinds of stigma. This is what Anna said in an interview:

My mother wears a veil and when we are together, talking...we both have strong personalities and talk in loud voices and she doesn't care what anyone thinks and I sometimes think that she ought to calm down and not draw attention to herself. She often wears trousers and ordinary clothes with her veil, but when she can't be bothered to dress up she wears her abaya, the black cloak, and people spit at her and comment on her clothing (Interview, 22-03-2013).

Victoria was born in Somalia, but came to Sweden when she was a child. When she is travelling in Sweden for her work she is often questioned at hotels: "What is a black woman doing here?" (Interview, 23-05-2012). Victoria shudders at the thought of entering a hotel dining room and eating breakfast, because she is always stared at. This makes her feel very uncomfortable. In addition to challenging the notions about where black women can be seen, Victoria also questions class affinity. In her research, Philomena Essed (Essed, 1991, p. 151-152) shows how black women staying at hotels in Europe have been regarded as prostitutes by hotel staff.

There is a gender and sometimes a religious and class dimension in the experiences one has as "nonwhite"; something that is evident in the above example and is substantiated by others (Kalonaityté, Kawesa, \& Tedros, 2007; Motsieloa, 2003; Pred, 2000; Sawyer, 2000; Schmauch, 2006). Men are more vulnerable in violent situations than women and appear to be more open to being challenged, whereas girls and young women experience that they are often regarded as being sexually available and/or have no right to refuse sexual invitations. This is often based on colonial notions and racist views, but can sometimes be combined with religious preconceptions, for example about Muslims. Different identities interact intersectionally.

As already indicated, many of the "non-white" men we interviewed said that they are often subjected to police controls at border crossings. This is also the case when driving-and especially if they are driving a "posh" car (Lambert, 2010). Mohammed is in his 40s and works in the building industry. He has been stopped by the police several times when driving, which can be interpreted as being connected with him having dark skin. When he told his "white" workmates about this they didn't believe him. However, after a company party Mohammed drove a couple of his workmates home and was stopped by the police who suspected him of driving an unregistered taxi. After a while he was able to continue his journey, but was soon stopped again by the police. This made Mohammed's friends so angry that they challenged the police officers about their behaviour. They now understand that Mohammed's experiences are quite different to theirs, and realise that the stories of everyday violations are true (Focus group 28-11-2013).

Other classic settings that are often referred to in the interviews, and where phenotypical markers and being male play an important role, are pubs and restaurants. Peter describes an incident outside a club in Malmö when he approached a security guard to ask which music was being played in the club, but was brusquely dismissed:

He pushed me and said "go away". I said: "Wait a minute, I asked a simple question so you could give me an answer rather than push me'. He produced his baton and said: 'Get out of here, otherwise'. So I said: 'Otherwise what?' He then started to hit me. 
Pang on the arm. Two other guards appeared and hit me all over my body. I started to bleed and then fell down. There were about 100 people there. Not one of them reacted. But two black guys came running over. I got up and they stopped. They left and I had blood all over me and I phoned the police. And I said: 'you must come because I've been assaulted'. They said: 'No, go away from there. The guards are right. If they say that you can't go in then you mustn't go in', I said: 'I don't want to go in, I've been assaulted, can you come?' 'No, we don't have a car, we're not able to. Just leave' (Interview, 22-03-2012).

Esmail described what happened when he tried to enter a club but was stopped by the security guards at the door who denied him access. "Unfortunately they often check for ethnicity", he said. He started a discussion with the guards about his rights, which irritated one of them to the extent that he pushed him and told him to go away. At about the same time a group of police officers arrived at the scene and followed Esmail. He said to the policemen: "Are you having me on"? One of the policemen answered: "What's it to you, shut your mouth". All of a sudden Esmail was pushed into a police van by a female police officer and inside the van another policeman boxed his ears. Esmail started to laugh, which resulted in further punishment. "Another put his knee in my face. They know what to do-it is an abuse of power that they use because they think they have the right to do what they like". Esmail was arrested: "They pulled my arms until they hurt and stripped me of my clothes. Another policeman said: Here you are now you bloody kanake". When Esmail asked why they had taken his clothes another policeman replied: "Shut up wog!" When he was released Esmail reported the event, but it was ignored (Interview, 29-11-2013).

Peter was beaten up by private security guards and Esmail by the police because they had challenged their authority and thereby tested the boundaries. These two incidents can be seen as examples of "public policing", when guards or doorkeepers assert their rights to determine who should cross or enter and the police assert their rights to exert force based on ethnicity/race. The people with an African background that we interviewed and their friends seldom reported hate crime incidents to the police, because they knew that nothing would be done about the problem (under-policing). The understanding was that the police did not prioritise this kind of crime. On the contrary, many are of the opinion that the police single people out as suspects depending on their different phenotypical markers (over-policing); something that is also evident in the above examples (Focus group 14-09-2012 and Focus group 28-11-2013).

The interviews show that there is interplay between different categories, such as race, ethnicity, gender, class and religion, and that an intersectional perspective is important when analysing the vulnerability that many of the informants expressed.

\section{Conclusions}

In the study, "non-whites", and in particular Afroswedes, are in the foreground. As the interviews show, prejudices about "non-whites" are sometimes combined with religious, class and gender-based fallacies. Different identity positions work intersectionally. According to Craig-Henderson \& Sloan (2003), victims of racism are often characterised as belonging to extremely negative stereotyped groups and as part of a visible minority. Even though the Swedish self-image often leads to the denial of racist structures in society, and the fact that race is important, our material shows that these standpoints are incorrect. Race is done by for example using an abundance of words and expressions in more or less denigrating ways, such as when a "white" calls a "nonwhite" a "nigger" - a term that all the informants regard as insulting and racist-and by too many white Swedes asserting their rights to speak as they have "always done". As our interviews show, prejudices and stereotypes that are often based on colonial notions can lead to verbal harassment where power relations are of great importance. Racist expressions and harassment are not always counted as hate crime in a legal sense; the lines between them can be very thin (Felson \& Boba, 2010; Iganski, 2008). Nevertheless, these racist expressions can be extremely offensive and painful for those who have been targeted, and can erode a victim's self-confidence and reduce his or her possibilities of living a good life.

Ideas about race also influence "private" and "public" policing. In other words, race cannot be disregarded in today's Swedish society. However, perceptions of difference, such as visible differences, are part of a relational process, in that differences are negotiated in society and are not static. This is why prevailing situations and relations can be changed (Osanami Törngren, 2011).

The case of Peter Mangs outlined at the beginning of the article shows that the victims were punished for geographically being in the "wrong" territory, which can be interpreted as "geographical hate". This indicates a kind of "private policing" of the "outsiders" who have crossed borders and "threatened" Swedishness. The perpetrators punish those who cross borders/boundariespeople with dark skin and are regarded as culturally and religiously different-in a variety of ways. Many scholars refer to hate crimes as message crimes that send clear warnings to all members of the victim's group to not cross borders/boundaries so that they too end up as victims (Ahn Lin, 2009). The individual fear that a person who has been victimised can feel is followed by a collective fear for the entire group or other minority groups (Ahn Lin, 2009; Iganski, 2008). The spatial influence of hate crime also expresses itself in a way that 
perhaps makes people reluctant to go to specific places because they are afraid of being exposed to racist policing or hate crime (Iganski \& Lagou, 2009). For example, in connection with the Peter Mangs' shootings, many with dark phenotypical markers were afraid to go out and thereby had their lives curtailed.

The denial of racist structures and the importance of notions about race can also lead to hate crime and other forms of racial harassment not being attended to in an appropriate way by the authorities. Hate crimes committed by private actors- "private policing" - are illegal, although in our empirical material there are numerous examples of how the police, as a government agency, "legally" carry out "public policing" in a way that the informants experience as hate crime or hate crime acts. These grey zones are important to highlight. The different empirical examples of "public policing" in our study deal with black people's experiences of abusive and offensive encounters with the police. The informants have all understood that they are singled out and treated harshly due to their phenotypical markers (race/ethnicity profiling); an action that has led them to doubt the state's ability to deal with them in a just and equitable way. The people that we interviewed seldom reported hate crime incidents to the police because they knew that the police would not do anything about them ("under-policing"). Rather, many of them said that the police singled out people as suspects due to their phenotypical markers ("over-policing"), which suggests that in many cases racist discourses and structural/institutional racism affect police work. One consequence of this is that hate crime legislation will be undermined if those who feel that they have been exposed to hate crime do not dare to or think that it is futile to report people who carry out "public policing". It is therefore very important that the Police priorities creating trust from different minority groups by educating police officers about hate crime, antidiscrimination work, and attitudes connected to minorities, as well as by establishing special hate crime units which specialize in hate crimes. These measures must also be a part of a public antidiscrimination policy.

\section{Acknowledgements}

The research was made possible through funding from The Swedish Research Council and The Swedish Crime Victim Compensation and Support Authority.

\section{Conflicts of Interest}

The author declares no conflict of interest.

\section{References}

Ahn Lin, H. (2009). Race, Bigotry, and Hate Crime: Asian Americans and the Construction of Difference. In B.
Perry (Ed.). Hate Crime: The Victims of Hate Crime (Volume 3). Westport, Connecticut, USA: Praeger.

Alvarez, R. (1995). The Mexican-US border. The making of an anthropology of borderlands. Annual Review of Anthropology, 24, 447-470.

Alvesson, M., \& Sköldberg, K. (1994). Tolkning och reflektion-vetenskapsfilosofi och kvalitativ metod. Lund, Sweden: Studentlitteratur.

Anthias, F., \& Yuval-Davis, N. (1992). Racialized Boundaries. Race, Nation. Gender, Colour and Class, and the Antiracist Struggle. London, UK: Routledge.

Berg, L. (1997). När Sverige upptäckte Afrika. Stockholm, Sweden: Prisma.

Bonilla-Silva, E. (2010). Racism without Racists: Colorblind Racism and the Persistence of Racial Inequality in the United States. Lanham, USA: Rowman \& Littlefield Publishers.

Bowling, B., \& Phillips, C. (2002). Racism, Crime and Criminal Justice. Harlow, UK: Longman.

Brå. (2013). The Swedish Crime Survey 2012. In Hatbrott 2012, Rapport 2013:16. Stockholm, Sweden: Brå.

Brah, A. (1993). Difference, Diversity, Differentiation: Processes of Racialisation and Gender. In J. Wrench \& J. Solomos (Eds.), Racism and Migration in Western Europe. Oxford, UK: Berg.

Bryman, A. (2012). Samhällsvetenskapliga metoder. Malmö, Sweden: Liber.

Catomeris, C. (2004). Det ohyggliga arvet: Sverige och främlingen genom tiderna. Stockholm, Sweden: Ordfront.

Charmaz, K. (2006). Constructing grounded theory: A practical guide through qualitative analysis. Los Angeles, USA: Sage.

Craig-Henderson, K., \& Sloan, R. (2003). After the Hate: Helping Psychologist Help Victims of Racist Hate Crime. Clinical Psychology: Science and Practice, 10(4), 481-490.

Crenshaw, K. (1991). Mapping the Margins: Intersectionality, Identity Politics, and Violence against Women of Color. Stanford Law Review, 43, 1241-1299.

van Dijk, T. (1993). Elite Discourse and Racism. Newbury Park, CA, USA: Sage Publications.

Essed, P. (1991). Understanding Everyday Racism. An interdisciplinary Theory. Newbury Park, CA, USA: Sage Publications.

Fassin, D. (2011). Policing Borders, Producing Boundaries. The Governmentality of Immigration in Dark Times. Annual Review of Anthropology, 40, 213226.

Felson, M., \& Boba, R. (2010). Crime and Everyday Life. Thousand Oaks, CA, USA: Sage.

Gadd, D., \& Dixon, B. (2009). Posing the "Why" Question: Understanding the Perpetration of Racially Motivated Violence and Harassment. In B. Perry (Ed.). Hate crimes. Understanding and Defining Hate Crime (Volume 1). Westport, CT, USA, and London, UK: Praeger. 
Goldberg, D. (2006). Racial Europeanization. Ethnic and Racial Studies, 20(2), 331-364.

Granqvist, R. (2001). Virvlande svarta lemmar och goda svenskar i Kongo-Om svensk rasism i vardande. In M. McEachrane, L. Faye (Eds.), Sverige och de Andra, Postkoloniala perspektiv. Stockholm: Natur och Kultur; 2001.

Green, D., Strolovitch, D., \& Wong, J. (1998). Defended neighborhoods, integration and racially motivated crime. The American Journal of Sociology, 104(2), 372-403.

Hall, N. (2005). Hate Crime. London, UK, and New York, USA: Routledge.

Hall, S. (1997). The Spectacle of the "other". In S. Hall (Ed.), Representation, Cultural Representations and Signifying Practices. London, UK: Sage Publication.

Harries, D. (1999). The Stories, the Statistics, and the Law. Why "Driving while Black" Matters. Minnesota Law Review, 84, 265-326.

Hübinette, T., Beshir, S., \& Kawesa, V. (2014). Afrofobi. En kunskapsöversikt över afrosvenskars situation $i$ dagens Sverige. Botkyrka, Sweden: Mångkulturellt centrum.

Hübinette, T., Hörnfeldt, H., Farahani, F., \& Rosales, R. L. (2012). Om ras och vithet $i$ det samtida Sverige. Botkyrka, Sweden: Mångkulturellt centrum.

Hydén, S., \& Lundberg, A. (2004). Inre utlänningskontroll $i$ polisarbete-mellan rättsstatsideal och effektivitet $i$ Schengens Sverige. Linköping, Sweden: Linköping Studies in Art and Science.

Iganski, P. (2008). Criminal Law and the Routine Activity of "Hate Crime". Liverpool Law Review, 29(1), 1-17.

Iganski, P. (2009). Hate Crime as a Scholarly Domain. In B. Perry \& P. Iganski P (Eds.), Hate Crimes: The Consequences of Hate Crime (Volume 2). Westport, CT, USA and London, UK: Praeger.

Iganski, P., \& Lagou, S. (2009). How Hate Crime Hurt More: Evidence from the British Crime Survey. In B. Perry \& P. Iganski P (Eds.), Hate Crimes: The Consequences of Hate Crime (Volume 2). Westport, CT, USA and London, UK: Praeger.

Jones-Brown, D., \& Maule, B. (2010). Racially Biased Policing. A Review of the Judicial and Legislative Literature. In S. Rice \& M. White (eds.), Race, Ethnicity, and Policing: New and Essential Readings. New York, USA: New York University Press.

Kalonaityté, V., Kawesa, V., \& Tedros, A. (2007). Att färgas av Sverige: Upplevelser av diskriminering och rasism bland ungdomar med afrikansk bakgrund $i$ Sverige. Stockholm, Sweden: Ombudsmannen mot etnisk diskriminering.

Lambert, J. (2010). Driving While Black. A Statistician Proves that Prejudice Still Rules the Road In S. Rice \& M. White (eds.), Race, Ethnicity, and Policing: New and Essential Readings. New York, USA: New York University Press.
Lamont, M., \& Molnár, V. (2002). The study of boundaries in the social sciences. Annual Review of Anthropology, 28, 167-195.

Lappalainen, P. (2005). Det blågula glashusetStrukturell diskriminering i Sverige. Stockholm, Sweden: Statens offentliga utredningar.

McDevitt, J., Levin, J., \& Bennett, S. (2003). Hate crime offenders: An Expanded Typology. In B. Perry (Ed.). Hate and Bias Crime. A reader. New York, USA, and London, UK: Routledge.

Miller, R. L. (2000). Researching life stories and family histories. London, UK: Sage.

Motsieloa, V. (2003). "Det måste vara någonting annat". En studie om barns upplevelser av rasism i vardagen. Botkyrka, Sweden: Mångkulturellt Centrum.

Osanami Törngren, S. (2011). Love ain't got no color? Attitudes toward interracial marriage in Sweden. Norrköping, Sweden: Linköping University/REMESO.

Perry, B. (2001). In the name of hate. Understanding Hate Crimes. New York, USA, and London, UK: Routledge.

Perry, B. (2003). Hate and Bias Crime. A reader. New York, USA, and London, UK: Routledge.

Perry, B. (2009). The sociology of hate: Theoretical approaches. In B. Perry (Ed.), Hate crimes. Understanding and Defining Hate Crime (Volume 1). Westport, CT, USA, and London, UK: Praeger.

Petrocelli, M., Piquero, A., \& Smith, M. (2003). Conflict theory and racial profiling: An empirical analysis of police traffic stop data. Journal of Criminal Justice, 31(1), 1-11.

Pred, A. (2000). Even in Sweden. Racialized Spaces and the Popular Geographical Imagination. Berkeley, USA: University of California Press.

Ray, L., \& Smith, D. (2001). Racist offenders and the Politics of "Hate Crime". Law and Critique, 12, 203-221.

Rice, S., \& White, M. (2010). Race, Ethnicity, and Policing: New and Essential Readings. New York, USA: New York University Press.

Sawyer, L. (2000). Black and Swedish. Racialisation and the Cultural politics of Belonging in Stockholm, Sweden. (Doctoral Dissertation). Santa Cruz, USA: University of California.

Schmauch, U. (2006). Den osynliga vardagsrasismens realitet. No 43. Umeå, Sweden: Akademiska avhandlingar vid Sociologiska institutionen, Umeå University.

Sumartojo, R. (2004). Contesting place: Anti-gay and lesbian hate crime in Columbus, Ohio. In C. Flint (Ed.), Spaces of hate: Geographies of discrimination and intolerance in the U.S.A (pp. 87-108). New York, USA: Routledge.

Weitzer, R. (2010). Race and Policing in Different Ecological contexts. In S. Rice \& M. White (Eds.). Race, Ethnicity, and Policing: New and Essential Reading. New York, USA: New York University Press. 
Weitzer, R., \& Tuch, S. (2002). Perceptions of Racial Profiling: Race, Class and Personal Experience. Criminology, 40(2), 435-456.

Wigerfelt, A., \& Wigerfelt, B. (2014). Everyday Racism and Hate Crime in a Small Swedish Town. OMNES:
The Journal of Multicultural Society, 5(2) (forthcoming).

Yuval-Davis, N. (2011). The Politics of Belonging. Intersectional Contestations. London, UK: Sage.

\section{About the Authors}

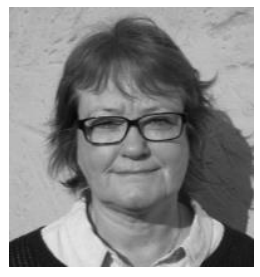

\section{Dr. Berit Wigerfelt}

Berit Wigerfelt has a PhD in Ethnology and is Associate Professor in International Migration and Ethnic Relations (IMER) at Malmö University, The Institute for Migration, Diversity and Welfare, Sweden. She has written articles and books about youth culture, multiculturalism in school, ethnicity, racism and hate crime.

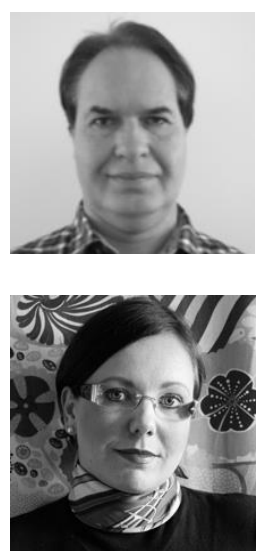

\section{Dr. Anders S. Wigerfelt}

Anders S Wigerfelt has a PhD in History and is Associate Professor in IMER. He is project leader of two research project: Hate Crime in Skåne and Hate Crime-A Challenge to Democracy. He has written articles and books about migration, racism, hate crime, multiculturalism, diversity and refugee policy.

\section{Dr. Jenny Kiiskinen}

Jenny Kiiskinen has a PhD in IMER and holds a post doc position at MIM (Malmo Institute for Studies of Migration, Diversity and Welfare) at Malmö University. Earlier research focuses on populist parties and mainstream parties reactions. She is now working in a research project about hate crimes and has, among others, written about anti-Semitism and racism in a hate crime context. 